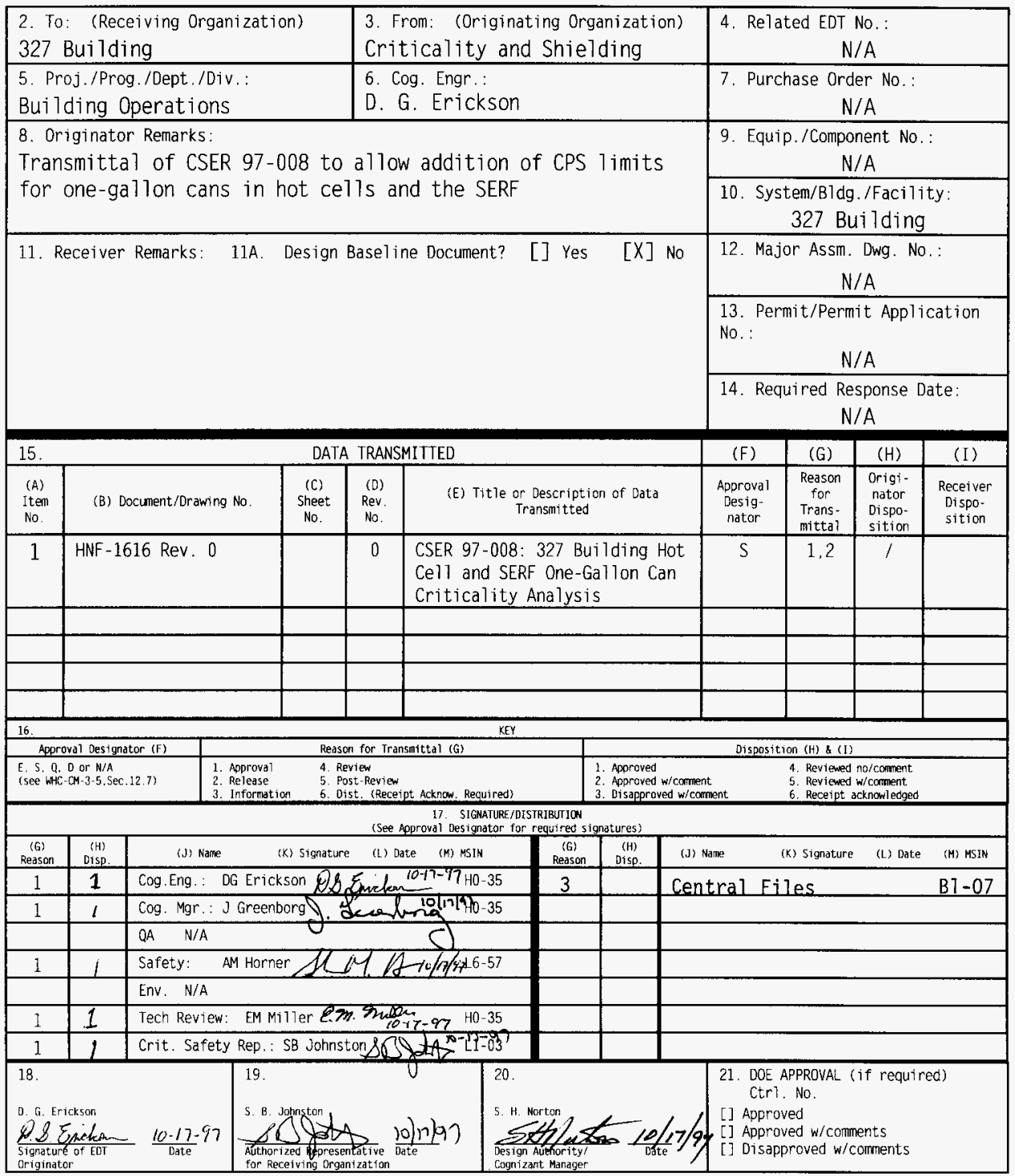




\begin{tabular}{|l|l}
\hline 1. Identification Nimber:327-BWHC-97-026 & USQ SCREENING \\
\hline
\end{tabular}

2. Title: HNF-1616. Rev, 0: CSER-97-008, 327 Builoing hot Cell and SERF One-Gallon Can Criticality Analysis

INSTRUCTIONS: $\quad$ Respond to each question and provide justification for each response. A restatement of the question does not constitute a satisfactory justification or basis. An adequate justification provides sufficient explanation such that an independent reviewer could reach the same conclusion based on the information provided [DOE 5480.21 . 10.e.1].

QUESTIONS

1. Does the proposed change or occurrence represent a change to the facility or procedures as described in the Authorization Basis? [] N/A [X] NO [] res/Maybe

BASIS: PAL-SAR-327. 327 Building Safety Analysis Report (SAR). Section 6.2.4 Criticality addresses the potential for an accidental criticality and the controls that exist in the 327 facility to minimize that potential to the point that it is considered virtually incredible (Section 6.4. Risk Assessment. The proposed change in the subject CSER does not impact that potential.

2. Woes the proposed change or occurrence represent conditions that have not been altalyzed in the Authorization Bas is?
[] N/A
[X] No
[?] Yes/Maybe

BASI5: The inclusion of waste buckets in the subject CSER represents conditions analyzed in PNL-SAR-327. Sections 6.2.4. Criticality and 6,4. Risk assessment.

3. Does the proposed change represent a test or experinent NoT described in the Authorization Basis that may affect the safe operation of the facility? [] $\mathrm{N} / \mathrm{A} \quad[\mathrm{X}]$ No [] Yes/Maybe

BASIS: Experimental and/or test activities are not covered by the subject CSER

4. Loes the proposed change or occurrence represent a change to the Technical Safety Requirements or a reduction in the margin of safety cefined in the Technical Safecty Requirements?
[] $\mathrm{N} / \mathrm{A}$
$[X]$ No
[] Yes/Maybe

BASIS: PNL-LIM-327, 327 Building Operating Limits (OSR) addresses limits for batches of moderated fissionable materials, FBR fuel pins. and N-Reactor fuel. The inclusion of waste bucket limits utilizes the same methodology for analysis as for current limits. The subject CSER specifies that Double Contingency, OSR Limit 1.1. shall be complied with through mass and redistribution controls. It aiso specifies that fissionable material batches based solely on mass and number or number limits shall not exceed $45 \%$ of a critical mass or a critical number, in compliance with OSR Limit 2.7.

WSOE * Alan M. Horner

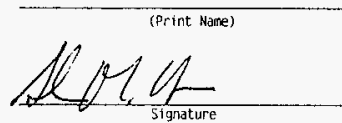
Date:

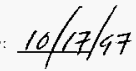

USQE \#2 John F. Henderson

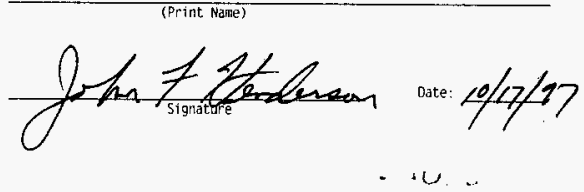

If there is a YES/MAYBE response to questions $1,2,3$ or 4 , then a USQ Evaluation must be completed

The following guidance should be considered when completing this screening. This guidance should not be considered all-inclusive: additional factors may need to be considered depending on the nature of the proposed change

Does the proposed change:

Modify, add. or delete a safety class function of a structure. system or component stated in the authorization basis?

Alter the design of a structure. system or component as described in the authorization basis?

Madify. add. or delete the description of coeration. operating environnent. or andiyses of any system or component described in the authorization basis?

Modify. add. delete or conflict with any of the design bases stated in the authorization basis?

Conflict with the principle or general desfon criteria stated in the authorization basis?

Modify. add. or delete any plant design features described in the authorization basis?

Modify, add, or delete a flow diagrar or facility drawing provided in the authorization basis?

create the potential for new systen or component interactions (e.g. Seismic, electrical breaker coordination)? 


\section{CSER 97-008: 327 Building Hot Cell and SERF One-Gallon Can Criticality Analysis}

David G. Erickson

Fluor Daniel Northwest, Inc., Richland, WA 99352

U.S. Department of Energy Contract DE-AC06-96RL13200

EDT/ECN: 622983

Org Code: 403

B\&R Code: EX3120020
UC: 507

Charge Code: K7A22

Total Pages: 13

Key Words: Criticality, Analysis, CSER, 327 Building, Hot Cell, One-gallon can

Abstract: This CSER gives the limits for the storage of one-gallon cans in the hot cells and the SERF in the 327 building.

TRADEMARK DISCLAIMER. Reference herein to any specific commercial product, process, or service by trade name. trademark, manufacturer, or otherwise, does not necessarily constitute or imply its endorsement, recommendation, or favoring by the United States Government or any agency thereof or its contractors or subcontractors.

Printed in the United States of America. To obtain copies of this document. contact: Document Control Services. P.0. Box 950, Mailstop H6-08, Richland WA 99352. Phone (509) 372-2420: Fax (509) 376-4989.
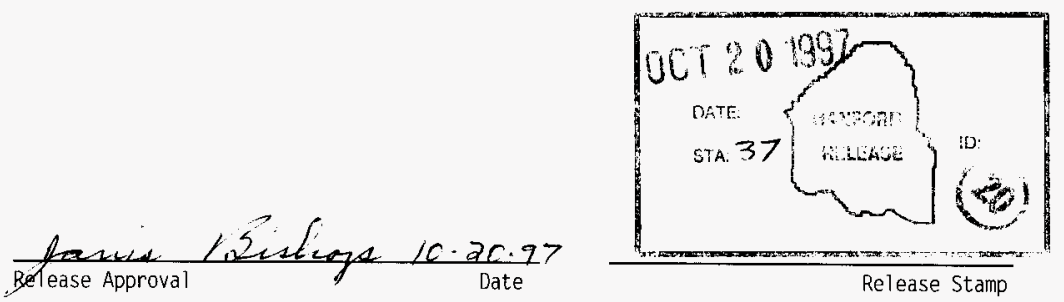

\section{Approved for Public Release}


HNF-1616 Rev. 0

\section{CONTENTS}

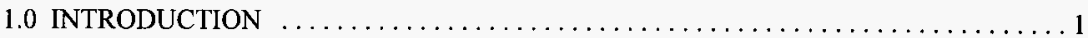

2.0 DESCRIPTION OF SYSTEM AND FACILITY $\ldots \ldots \ldots \ldots \ldots \ldots \ldots \ldots \ldots$

3.0 REQUIREMENTS DOCUMENTATION $\ldots \ldots \ldots \ldots \ldots \ldots \ldots \ldots \ldots \ldots \ldots \ldots \ldots$

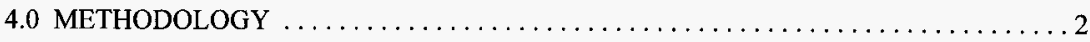

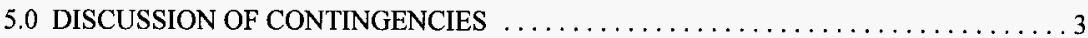

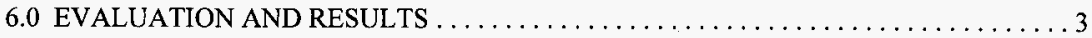

7.0 DESIGN FEATURES AND ADMINISTRATIVELY CONTROLLED LIMITS AND

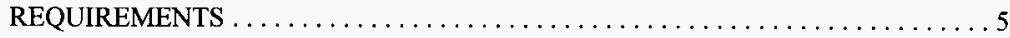

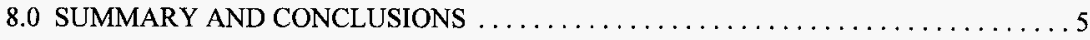

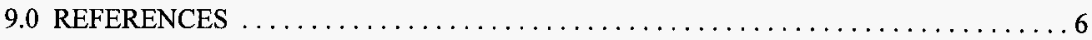

APPENDIX A INDEPENDENT REVIEW $\ldots \ldots \ldots \ldots \ldots \ldots \ldots \ldots \ldots \ldots \ldots \ldots \ldots$

APPENDIX B CALCULATION OF NUMBER OF CANS IN A CELL . . . . . . . B-1 
HNF-1616 Rev. 0

This page intentionally left blank 


\section{CSER-97-008}

Title: CSER 97-008: 327 Building Hot Cell and SERF One-Gallon Can Criticality Analysis

Prepared by: D. E Uakan Date: 10-17-97

D. G. Erickson, Criticality and Shielding

Reviewed by:Ederad 127202

Date: $10-17-97$

E. M. Miller, Criticality and Shielding

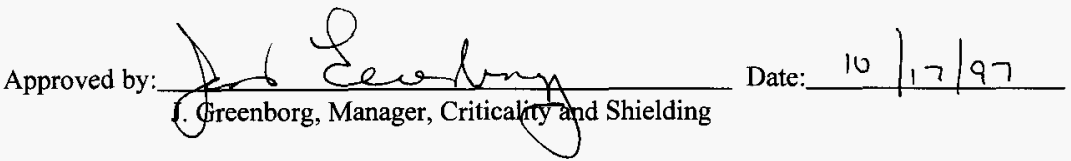

\subsection{INTRODUCTION}

The 327 Building is used to perform post irradiation testing of fissionable materials in remotely manipulated hot cells. Historically, scrap pieces of fuel cladding, cleanup materials, and other items have been placed into one-gallon paint cans for storage and ultimately disposal. These cans of materials had been assumed to contain no (or essentially no) fissionable materials, and therefore were not specifically controlled for material accountability.

Recently, eight (8) cans with high radiation levels were selected be assayed for content. These cans contained from 0 to 2.5 grams of fissionable material, with an average of 1 gram per can. Since several of the hot cells contained a significant quantity of the cans, concerns were raised as to whether a CPS nonconformance had occurred, and should the cans have some limits for operation placed on them. This analysis is a response to the concerns raised, and gives guidance for incorporating operating limits for the one-gallon waste cans.

\subsection{DESCRIPTION OF SYSTEM AND FACILITY}

The 327 building canyon contains many separate hot cells. Each of the hot cells has a mass limit on scrap and a number limit on fuel pins. The hot cells of concern are cells A through I plus the Special Environment Radiometallurgy Facility (SERF) operating area and storage cell. A description of each cell from the 327 building SAR (PNL-SAR-327, 1995) is given in Table 1. The hot cells are separated from each other by more than $1.8 \mathrm{~m}(6 \mathrm{ft}$.). All material transfers between cells are made using external transportation casks. 
Table 1. Description of Cells and SERF

\begin{tabular}{|c|c|c|c|c|}
\hline \multirow{2}{*}{ Cell } & Wall Material & Wall Thickness & \multicolumn{2}{|c|}{ Interior Dimensions $(\mathrm{L} \times \mathrm{W} \times \mathrm{H})$} \\
\cline { 4 - 5 } & & $\mathrm{cm}(\mathrm{in})$. & $\mathrm{cm}$ & $(\mathrm{in})$. \\
\hline A & Cast Iron $^{*}$ & $46(18)$ & $290 \times 137 \times 249$ & $(114 \times 54 \times 98)$ \\
\hline B & Cast Iron $^{*}$ & $38(15)$ & $183 \times 132 \times 131$ & $(72 \times 52 \times 51.5)$ \\
\hline C & Cast Iron $^{*}$ & $27(10.5)$ & $183 \times 132 \times 131$ & $(72 \times 52 \times 51.5)$ \\
\hline D & Cast Iron $^{*}$ & $27(10.5)$ & $183 \times 132 \times 131$ & $(72 \times 52 \times 51.5)$ \\
\hline E & Cast Iron $^{*}$ & $27(10.5)$ & $183 \times 132 \times 131$ & $(72 \times 52 \times 51.5)$ \\
\hline F & Cast Iron $^{*}$ & $46(18)$ & $244 \times 152 \times 249$ & $(96 \times 60 \times 98)$ \\
\hline G & Cast Iron $^{*}$ & $27(10.5)$ & $312 \times 191 \times 253$ & $(123 \times 75 \times 99.5)$ \\
\hline H & Cast Iron $^{*}$ & $27(10.5)$ & $163 \times 140 \times 216$ & $(64 \times 55 \times 85)$ \\
\hline I & Cast Iron $^{*}$ & $27(10.5)$ & $132 \times 122 \times 157$ & $(52 \times 48 \times 62)$ \\
\hline SERF operating area & Steel $^{*}$ & $46(18)$ & $366 \times 183 \times 240$ & $(144 \times 72 \times 96)$ \\
\hline SERF storage cell & Concrete $^{*}$ & $61(24)^{*}$ & $122 \times 122 \times 150$ & $(48 \times 48 \times 60)$ \\
\hline
\end{tabular}

- See PNL-SAR-327 for additional information.

Currently there are limits for batches of moderated fissionable materials, FBR fuel pins, and $\mathrm{N}$ Reactor fuel. New limits are necessary for the one-gallon cans.

\subsection{REQUIREMENTS DOCUMENTATION}

There are no unique requirements applicable to this evaluation.

\subsection{METHODOLOGY}

The method used for this analysis was to set the limits based on $45 \%$ of the maximum subcritical concentrations or densities for aqueous solutions reflected by an effectively infinite thickness of water for ${ }^{239} \mathrm{Pu},{ }^{235} \mathrm{U}$, and ${ }^{233} \mathrm{U}$ and convert this data to mass limits for each can, and for number of cans in a batch. This data came from the single parameter data found in Pruvost (1996), Nuclear Criticality Safety Guide.

The limits are based on homogeneous solutions of the specified isotopes. For the operation described here, the material will be in finite round cans. The limits therefore have additional conservatism due to the increased effective area from the space around the cans. 
This methodology is the same as used for the current limits. This also allows operations to continue utilizing the same methods for calculating how much material is allowed in a cell based on the fraction of the limit each different material present.

\subsection{DISCUSSION OF CONTINGENCIES}

Since it is assumed that the system is optimally moderated, and fully reflected, there are no contingencies associated with those parameters. The parameters of concern are can mass, hot cell areal density and can stacking limit. Each of these parameters will be discussed below.

Since the limiting per can mass is based upon $45 \%$ of the maximum subcritical concentration limit, if all cans were double batched, the system would still be well subcritical. This is highly unlikely since a check of eight (8) cans showed that the average can contains less than a gram of fissionable material.

The number of cans allowed in a cell is based upon $45 \%$ of the maximum subcritical areal density, with the cans uniformly spread throughout the cell and all cans filled to the maximum allowable mass. The concern here is the unlikely circumstance that the cans are all somehow crushed. If double the allowed number of cans were in a cell, and the cell were collapsed the system would still be subcritical.

The can stacking limit is based on the maximum subcritical areal density, and the dimensions of the cans. In the unlikely event that a cell collapses, thereby crushing the cans, if all the floor area had cans stacked to the limit, exceeding the number of cans limit for the cell, the system would still be subcritical. If one or two stacks of cans in a cell were to exceed the stack height limit, without exceeding the number of cans limit for the cell, it may exceed the areal density subcritical limit in a localized region. However, the system would still be subcritical, since the area involved would be to small to act as an infinite slab, the steel of the cans would lower the reactivity, and the system would still not likely be optimally moderated. Therefore, the double contingency principle would not be violated, since the cans would have to be collapsed and fissile material would have to be added to approach a critical condition. Also, the conservatisms of fissile mass, moderation, geometry and reflection make the necessary amount of added fissile material more than that required for a minimum critical condition.

The assumption of optimal moderation, and full reflection also allows the continued use of fire fighting category A for the facility.

\subsection{EVALUATION AND RESULTS}

The maximum single parameter solution subcritical limits for ${ }^{239} \mathrm{Pu},{ }^{235} \mathrm{U}$, and ${ }^{233} \mathrm{U}$ from Pruvost, (1996) are given in Table 2. Because these are subcritical limits, they are less than the minimum critical values for the more conservative model of fissile isotope atom in water given in Carter, (1967). 
Table 2. Maximum Single Parameter Subcritical Limits (Pruvost, 1996).

\begin{tabular}{|c|c|c|c|}
\hline \multirow{2}{*}{ Parameter } & \multicolumn{3}{|c|}{ Isotope } \\
\cline { 2 - 4 } & ${ }^{239} \mathrm{Pu}$ & ${ }^{235} \mathrm{U}$ & ${ }^{233} \mathrm{U}$ \\
\hline $\begin{array}{c}\text { Maximum subcritical concentration, } \\
(\mathrm{g} / \mathrm{l})\end{array}$ & 7.3 & 11.6 & 10.8 \\
\hline $\begin{array}{c}\text { Maximum subcritical areal density, } \\
\left(\mathrm{g} / \mathrm{cm}^{2}\right)\end{array}$ & 0.25 & 0.40 & 0.35 \\
\hline
\end{tabular}

By utilizing the safety factor of $45 \%$ of the maximum subcritical concentration and converting from liters to gallons, the maximum permitted mass in a one-gallon container was calculated for each of the defined isotopes. The results of these calculations are given in Table 3 . These limits are considered upper limits for fissile material in the one-gallon cans for operations because these cans were to be deposited in alpha caissons that had a 15 gram per can limit (Friar, 1989.), and were filled under a procedure such as 3M-SOP-PTL-094 (1995) which called for a 12 gram limit per can.

Table 3. Operating Limits for One-gallon Cans in the Hot Cells and SERF

\begin{tabular}{|c|c|c|c|}
\hline Parameter & \multicolumn{3}{|c|}{ Isotope } \\
\cline { 2 - 4 } & ${ }^{239} \mathrm{Pu}$ & ${ }^{235} \mathrm{U}$ & ${ }^{233} \mathrm{U}$ \\
\hline $\begin{array}{c}\text { Maximum fissionable material mass per } \\
\text { one-gallon can }\end{array}$ & $12.4 \mathrm{~g}$ & $19.7 \mathrm{~g}$ & $18.4 \mathrm{~g}$ \\
\hline $\begin{array}{c}\text { Maximum number of one-gallon cans in hot } \\
\text { cells A - H and the SERF operating cell* }\end{array}$ & 206 & 207 & 194 \\
\hline $\begin{array}{c}\text { Maximum number of one-gallon cans in hot } \\
\text { cell I, and SERF storage cell* }\end{array}$ & 135 & 136 & 127 \\
\hline Maximum can stacking limit & 5 & 5 & 5 \\
\hline
\end{tabular}

If the number of can limits are to be used for different isotopes in one cell, they shall be combined by summing the number fraction of allowable cans of each isotope, and assuring the total does not exceed 1.0

The total number of cans of material allowed in each hot cell was then calculated. The same safety factor of $45 \%$ of the maximum subcritical areal density was used. The smallest area of each of the hot cells was calculated from Table 1, this was then multiplied by $45 \%$ of the allowable areal density, and then it was divided by the mass allowed in a can. This was completed for each of the defined isotopes and the minimum number of cans was then chosen for the limit. The results of all of the calculations may be found in Appendix B. Due to their significantly smaller size a separate limit is defined for hot cell I and the SERF storage cell. These results are also given in Table 3. 
Finally, the number of cans that could be stacked was calculated. This is based on the assumption that the cell is collapsed due to an earthquake, and the cans are crushed into a slab type geometry, and therefore must still be subcritical. The collapsed can condition is not a condition at which operations will be taking place, but is the result of a contingency accident. For operations the conservative mass limit based on $45 \%$ of the maximum subcritical fissile concentration is used. For the conservative model of the cell collapse, the configuration only needs to be safely subcritical. Assuming the maximum subcritical areal density, the maximum allowed can mass, and the approximate can outside diameter of $16.5 \mathrm{~cm}(6.5 \mathrm{in}$.), the average maximum subcritical can stack height for a uniform array is calculated. This gives heights of $5.5,5.5$, and 5.2 cans for ${ }^{239} \mathrm{Pu},{ }^{235} \mathrm{U}$, and ${ }^{233} \mathrm{U}$ respectively. Therefore, a stack of five (5) cans is an acceptable value without compromising criticality safety during operations. Considering the limited number of cans allowed in a cell, the average stack height in a cell would be about 2.5 cans for all of the above isotopes. Therefore, as the can stack height is increased in one area, it must decrease in another area. In the event of an earthquake, any taller stacks would tend to fall onto the lower areas, and the system would be more subcritical.

Open cans should be treated as scrap, and the inventories included with the scrap material inventory. This is due to the fact that the contents could spill into an uncontrolled geometry. These cans should not be included as a part of the can limit.

\subsection{DESIGN FEATURES AND ADMINISTRATIVELY CONTROLLED LIMITS AND REQUIREMENTS}

The administratively controlled limits applicable to this evaluation are the maximum mass per one-gallon can, and the maximum number of cans allowed in a cell and the can stack height.

No other fissionable material shall be interspersed within the foot print of the can array, or stacked on or below the cans.

\subsection{SUMMARY AND CONCLUSIONS}

This analysis shows that storage of one-gallon cans that may contain fissile materials in the hot calls of the 327 building can be done safely. Limits for the mass of fissionable materials allowed in each can, and the total number of cans allowed in each hot cell are given in Table 3 of Section 6. Utilizing the current methods of calculating fractional material limits, materials with different limits may be safely stored in each of the hot cells. 
HNF-1616 Rev. 0

\subsection{REFERENCES}

3M-SOP-PTL-094, 1995, F Cell Mill General Procedure, Pacific Northwest Laboratories, Richland Washington

Carter, R. D., G. R. Kiel, and K. R. Ridgway, 1968, ARH-600, Criticality Handbook, 1980 Revision, Atlantic Richfield Hanford Company, Richland, Washington.

Friar, D. E., 1989, SD-SQA-CSA-20124, CSAR 80-025, Packaging, Storage and Disposal of Solid Waste (Alpha Caissons), Westinghouse Hanford Company, Richland Washington

PNL-SAR-327, 1995, 327 Building Safety Analysis Report, Pacific Northwest Laboratories, Richland Washington

Pruvost, N. L., H. C. Paxton, Editors, 1996, LA-12808, Nuclear Criticality Safety Guide, Los Alamos National Laboratory, Los Alamos, New Mexico 
HNF-1616 Rev. 0

APPENDIX A

\section{INDEPENDENT REVIEW}

A-1 


\section{CHECKLIST FOR INDEPENDENT REVIEW}

Document Reviewed: CSER 97-008: 327 Building Hot Cell ans SERF One-Gallon Can Operating Limits

Yes No* NA

$\mathbb{X}[\mathrm{C}$ [ ] ]

$X]\left[\begin{array}{ll}{[} & {[}\end{array}\right.$

$\left[\begin{array}{lll}1 & {[}\end{array}\right]$

$[X][]$

$X][][]$

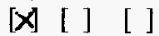

[ ] [ ] [X]

[ ] [ ] [X]

[ ] [ ] [ $[x]$

$\left[\begin{array}{lll}{[} & {[} & {[}\end{array}\right]$

[X] [ ] [ ]

$[x]\left[\begin{array}{ll}1 & {[}\end{array}\right]$

$[x][][]$

$X][][]$

$\left[\begin{array}{ll}{[} & {[x]}\end{array}\right.$

Problem completely defined.

Necessary assumptions explicitly stated and supported.

Computer codes and data files documented.

Data used in calculations explicitly stated in document.

Data checked for consistency with original source information as applicable.

Mathematical derivations checked including dimensional consistency of results.

[X] [ ] [ ]

Models appropriate and used within range of validity or use outside range of established validity justified.

Hand calculations checked for errors. Spreadsheet results should be treated exactly the same as hand calculations.

Software input correct and consistent with document reviewed.

Software output consistent with input and with results reported in document reviewed.

Limits/criteria/guidelines applied to analysis results are appropriate and referenced. Limits/criteria/guidelines checked against references.

Safety margins consistent with good engineering practices.

Conclusions consistent with analytical results and applicable limits.

Results and conclusions address all points required in the problem statement.

**Review calculations, comments, and/or notes are attached.

[X] [ ] [ ] Traceability

Document approved (i.e., the reviewer affirms the technical accuracy of the document).

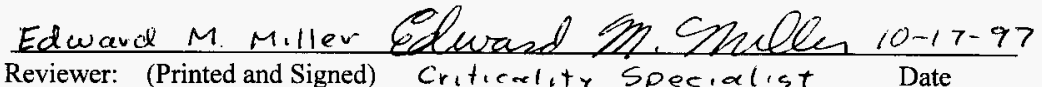

- $\quad$ All "NO" responses must be explained below or on an additional page.

** Any calculations, comments, or notes generated as part of this review should be signed, dated and attached to this checklist. 
HNF-1616 Rev. 0

APPENDIX B

CALCULATION OF NUMBER OF CANS IN A CELL 
HNF-1616 Rev. 0

Table 1 below, shows the results of the calculations of the maximum number of cans allowed in a cell for each cell, and each different isotope..The number of cans is calculated by taking $45 \%$ of the areal density times the area of the cell divided by the number of grams per can.

Table 1.

\begin{tabular}{|l|r|r|r|r|r|r|}
\hline Cell & L (in) & W (in) & $\mathrm{A}\left(\mathrm{cm}^{2}\right)$ & \multicolumn{3}{|c|}{ Number of Cans } \\
\hline A & 114 & 54 & 39716 & 360 & 363 & 340 \\
\hline B & 72 & 52 & 24155 & 219 & 221 & 207 \\
\hline C & 72 & 52 & 24155 & 219 & 221 & 207 \\
\hline D & 72 & 52 & 24155 & 219 & 221 & 207 \\
\hline E & 72 & 52 & 24155 & 219 & 221 & 207 \\
\hline F & 96 & 60 & 37161 & 337 & 340 & 318 \\
\hline G & 123 & 75 & 59516 & 540 & 544 & 509 \\
\hline H & 64 & 55 & 22710 & 206 & 207 & 194 \\
\hline I & 52 & 48 & 16103 & 146 & 147 & 138 \\
\hline SERF upper & 144 & 72 & 66890 & 607 & 611 & 573 \\
\hline SERF lower & 48 & 48 & 14864 & 135 & 136 & 127 \\
\hline
\end{tabular}

